\title{
Polymorphisms in the cytochrome P-450 (CYP) 1A1 and 17 genes are not associated with acne vulgaris in the Polish population
}

\author{
Michał Sobjanek ${ }^{1}$, Monika Zabłotna ${ }^{1}$, Magdalena Dobosz-Kawałko ${ }^{1}$, Igor Michajłowski ${ }^{1}$, \\ Wioletta Mędrzycka-Dąbrowska², Roman Nowicki ${ }^{1}$, Małgorzata Sokołowska-Wojdyło ${ }^{1}$
}

\author{
${ }^{1}$ Department of Dermatology, Venereology and Allergology, Medical University of Gdansk, Gdansk, Poland \\ Head of the Department: Prof. Roman Nowicki MD, PhD \\ ${ }^{2}$ Department of Nursing, Medical University of Gdansk, Gdansk, Poland \\ Head of the Department: Andrzej Chamienia MD, PhD
}

Postep Derm Alergol 2015; XXXII (5): 323-326

DOI: 10.5114/pdia.2014.44004

\begin{abstract}
Introduction: The pathogenesis of acne is complex, multifactorial and not well understood. The genetic background of this dermatosis is well documented.

Aim: To assess the frequency of $-34 \mathrm{~T}>\mathrm{C}$ single nucleotide polymorphism in the promoter of the CYP17 gene as well as $m 1(+6,235 \mathrm{~T}>\mathrm{C})$ and $m 2(+4,889 \mathrm{~A}>\mathrm{G})$ mutation in the coding region CYP1A1 gene acne patients from the Northern Polish population.

Material and methods: The study included 115 acne patients and 94 healthy controls (aged over 20) without acne in anamnesis. The CYP1A1 polymorphism was analyzed by polymerase chain reaction (PCR). The restriction fragment length polymorphism (RFLP) was used to analyze $m 1$ mutation and allele-specific PCR in the case of $m 2$ mutation. The CYP17 polymorphism was analyzed by RFLP. The results were evaluated by the Pearson's $\chi^{2}$ test.

Results: There were no statistically significant associations between allele and genotype frequencies between the acne and the control group.

Conclusions: We did not confirm the role of the CYP1A1 and CYP17 gene as predictor factors for acne development in the Polish population.
\end{abstract}

Key words: acne, genetic factors, cytochrome P-450, CYP1A1, CYP17, gene polymorphism.

\section{Introduction}

The pathogenesis of acne is complex, multifactorial and not well understood. Several factors such as abnormal keratinocyte function, excessive androgenic stimulation, sebum overproduction, hypercolonization by Propionibacterium acnes and inflammation have been implicated [1, 2].

At the beginning of the $20^{\text {th }}$ century, a German dermatologist - Herman Wener Siemens had demonstrated first a link between genetic inheritance and acne [3, 4]. Subsequent twin and genealogic studies have proven genetic determination of acne. Bataille et al. [5] in a study of 458 pairs of monozygotic and 1,099 pairs of dizygotic female twins, showed that $81 \%$ of the variance of the disease was attributed to genetic effects, and the remaining
$19 \%$ was attributed to environmental factors. Goulden et al. [6] in a study of 204 acne cases and 144 non acne control volunteers, suggested that the familial factor is important in determining individual susceptibility to adult persistent facial acne.

Despite the fact that genetic influence on the pathogenesis of acne is well documented, there is a relatively small number of publications concerning this field.

Previous investigations were focused on the role of polymorphisms in the tumor necrosis factor- $\alpha$ (TNF- $\alpha$ ), tumor necrosis factor receptor type 2 (TNFR2), Toll-like receptor 2 (TLR-2), insulin-like growth factor-I (IGF-I), mucin (MUC1), retinoic acid receptor $\alpha(R A R-\alpha)$, insulin-like growth factor-I (IGF-I), interleukin (IL) 1a, 4, 8, 10 and fibroblast growth factor receptor 2 (FGFR2), androgen re-

Address for correspondence: Michał Sobjanek MD, PhD, Department of Dermatology, Venereology and Allergology, Medical University of Gdansk, 7 Dębinki St, 80-211 Gdansk, Poland, phone: +48 583492 580, fax: +48 583492 583, e-mail: sobjanek@wp.pl Received: 15.10.2013, accepted: 2.01.2015. 
ceptor as well as cytochrome P450 (CYP) 1A1, CYP 17, CYP 21 genes [1, 7-16].

CYP are a multigenetically coded family of iron-containing hemoproteins, which catalyzes the metabolism of exogenous and endogenous products such as fatty acids, sterols, sex sterols, glucocorticosteroids, leukotrienes, prostaglandins, and vitamins $\mathrm{A}$ and E. CYP11A1 is involved in the metabolism of endogenous vitamin $A$ and retinoids, and its natural metabolites are morphogenic for the sebaceous glands [14, 15].

The human CYP1A1 gene is localized on chromosome 15q22-q24. The first discovered mutation (called m1) was a thymine-to-cytosine (T-to-C) transition situated at position 6235 creating an additional cleavage site for Msp/ in the 3'-flanking region 1,194 bp downstream of exon 7. The second mutation $-m 2$, is a replacement of adenine by guanine (A-to-G) at position 4889 in exon 7 [15].

Table 1. Genotype and allele frequencies of $-34 \mathrm{~T}>\mathrm{C}$ CYP17 gene and $m 1$ and $m 2$ CYP1A1 gene polymorphisms in acne patients and the healthy control group. Differences are not significant

\begin{tabular}{|c|c|c|}
\hline Variable & Controls & Acne \\
\hline \multicolumn{3}{|l|}{ CYP17 } \\
\hline Genotype frequency: & $N=94$ & $N=115$ \\
\hline $\mathrm{TT}$ & $34(36.2 \%)$ & $40(34.8 \%)$ \\
\hline TC & $43(45.7 \%)$ & $53(46.1 \%)$ \\
\hline CC & 17 (18.1\%) & $22(19.13 \%)$ \\
\hline Allele frequency: & $N=188$ & $N=230$ \\
\hline Allele T & $111(59.0 \%)$ & $133(57.8 \%)$ \\
\hline Allele C & 77 (41.0\%) & $97(42.2 \%)$ \\
\hline \multicolumn{3}{|l|}{ CYP1A1m1 } \\
\hline Genotype frequency: & $N=94$ & $N=115$ \\
\hline wt/wt & $80(85.1 \%)$ & 93 (80.9\%) \\
\hline $\mathrm{wt} / \mathrm{m} 1$ & 14 (14.9\%) & $22(19.1 \%)$ \\
\hline $\mathrm{m} 1 / \mathrm{m} 1$ & $0(0 \%)$ & $0(0 \%)$ \\
\hline Allele frequency: & $N=188$ & $N=230$ \\
\hline Allele wt & 174 (92.5\%) & $208(90.4 \%)$ \\
\hline Allele m1 & $14(7.5 \%)$ & $22(9.6 \%)$ \\
\hline \multicolumn{3}{|l|}{ CYP1A1m2 } \\
\hline Genotype frequency: & $N=94$ & $N=115$ \\
\hline wt/wt & $89(94.7 \%)$ & $106(92.2 \%)$ \\
\hline $\mathrm{wt} / \mathrm{m} 2$ & $5(5.3 \%)$ & $9(7.8 \%)$ \\
\hline $\mathrm{m} 2 / \mathrm{m} 2$ & $0(0 \%)$ & $0(0 \%)$ \\
\hline Allele frequency: & $N=188$ & $N=230$ \\
\hline Allele wt & $183(97.3 \%)$ & $221(96.1 \%)$ \\
\hline Allele $\mathrm{m} 2$ & $5(2.7 \%)$ & $9(3.9 \%)$ \\
\hline
\end{tabular}

wt - Wild type
The CYP17 gene is situated on chromosome 10q24.3 and encodes cytochrome P450c17 $\alpha$, which is one of the key enzymes in androgen biosynthesis. That enzyme mediates both steroid $17 \alpha$-hydrolase and 17,20-lyase activity. There is a polymorphism involving a single base change from $\mathrm{T}$ to $\mathrm{C}$ at the $5^{\prime}$ - untranslated region (UTR) in the CYP17 gene, which may create an additional SP-1 site (CCACC box) at 34 bp upstream from the initiation of translation. Increased promoter activity with an elevated level of CYP17 mRNA has been reported in variant sequences containing this polymorphism. Therefore, this polymorphism may influence the activity of the cytochrome P450c17 $\alpha$ enzyme and sex steroid synthesis which seems to alter the serum level of sex hormones such as androgen, progesterone and estrogen [14].

Considering the fact that the products of CYP1A1 and CYP17 genes may be involved in sebaceous unit function that genes seem to be a good candidate for an important acne factor.

In this study, $-34 \mathrm{~T}>\mathrm{C}$ single nucleotide polymorphism in the promoter of theCYP17 gene as well as the $m 1(+6,235 \mathrm{~T}>\mathrm{C})$ and $m 2(+4,889 \mathrm{~A}>\mathrm{G})$ mutation in the coding region CYP1A1 gene were assessed in relation to the risk of acne development in Northern Polish population.

\section{Material and methods}

The study included 115 acne patients and 94 healthy age- and sex-matched controls (aged over 20) without acne in anamnesis. The CYP1A1 gene polymorphism was analyzed by the polymerase chain reaction (PCR). The restriction fragment length polymorphism (RFLP) was used in the case of the $m 1(+6,235 \mathrm{~T}>\mathrm{C})$ mutation and allele-specific PCR in the case of the $m 2(+4,889 \mathrm{~A}>\mathrm{G})$ mutation. -34 T>C CYP17 gene polymorphism was analyzed by RFLP according to the methods described by Paraskevaidis et al. [15] and Rumianowski et al. [16]. The results were evaluated by the Pearson's $\chi^{2}$ test.

\section{Results}

The genotype distribution of all polymorphisms corresponded with Hardy-Weinberg equilibrium. There were no statistically significant association between allele and genotype frequencies between the acne and the control group (Table 1).

\section{Discussion}

The etiopathogenesis of acne vulgaris is multifactorial and associated with genetic and environmental aspects. The sebaceous gland function is regulated by various factors (hormones, cytokines, chemokines, grow factors) however vitamin A metabolites and androgens play a crucial role. Therefore, that might be the reason why CYP genes are possible acne gene candidates. 
Polymorphic variants of CYP family genes were associated with several inflammatory and neoplastic disorders but only few studies are concentrated on acne $[13-15,17]$.

The first molecular researches of genetic acne predisposition were performed at the end of the $20^{\text {th }}$ century. In 1998, Paraskevaidis et al. [15] found a trend to an overexpression of CYP1A1 $\mathrm{m} 1$ alleles in acne patients and normal frequency of $m 2$. Authors believed that the $m 1$ mutation might define a marker for alterations on regulatory sites, the biological efficacy of natural retinoids could be greatly impaired by their rapid metabolism to inactive compounds. A deficit of active natural retinoids may be implicated with the development of acne in some patients, due to abnormal sebocyte differentiation and hyperkeratinization of the follicular canal. Our preliminary study on a smaller group showed a two times higher incidence of CYP1A1 $m 1$ and $m 2$ mutations in the acne group compared to controls [18]. We have not revealed any association between CYP1A1 gene polymorphisms and acne in this study in spite of including twice as many patients.

The relationship between the CYP17-34T>C gene polymorphism was first observed by He et al. [14]. Authors revealed that a CYP14-34C/C homozygote Chinese man had a significantly increased risk of developing severe acne. A subsequent Chinese report revealed that the presence of base substitution thymine to cytosine in -34 CYP17 increases the risk of post adolescent acne in female subjects with increased androgen levels [19, 20]. In our study, we did not confirm these results. Caputo et al. [13] evaluated CYP21 gene mutations in a selected group of women with papulopustular and comedonal acne refractory to treatment, irregular menses and hirsutism. Authors revealed several different point mutations and demonstrated that a cohort of patients resistant to acne therapy can be carriers of or affected by non-classical 21-hydroxylase deficiency (late onset).

Yang et al. [17] analyzed the CAG repeat polymorphism in the androgen receptor gene and acne in the Chinese population. Their results indicate that polymorphism to be one of the candidate genetic markers for male acne susceptibility.

That inconsistent results suggest that genetic predisposition to acne is poligenetically coded and can be associated with the patient origin. Our and RomanianHungarian researches did not show any relationship between -308G >A TNF gene polymorphism and acne contrary to two Arabic studies. Also TNF-308G >A genotype frequencies of control individuals were different in Polish, Hungarian-Romanian and Turkish studies [7, 10, 20, 21].

\section{Conclusions}

Presented data did not confirm the role of the CYP1A1 and CYP17 gene as predictor factors for acne develop- ment in the Polish population. Results of our study as well as literature data indicate that genetic susceptibility to acne may vary in a different population. Further complex, multicenter investigations are strongly required.

\section{Conflict of interest}

The authors declare no conflict of interest.

\section{References}

1. Szabó K, Kemény L. Studying the genetic predisposing factors in the pathogenesis of acne vulgaris. Hum Immunol 2011; 72: 766-73.

2. Bergler-Czop B, Brzezińska-Wcisło L. Pro-inflammatory cytokines in patients with various kinds of acne treated with isotretinoin. Postep Derm Alergol 2014; 31: 21-8.

3. Siemens HW. Die Vererbung in der Aetiologie der Hautkrankheiten. In: Handbuch der Haut-und Geschlechtskrankheiten. Jadassohn J (ed.). Springer, Berlin 1929.

4. Siemens HW. Die Zwillingspathologie, Ihre Bedeutung, Ihre Methodik, Ihre Bisherigen Ergebnisse J. Springer, Berlin 1924.

5. Bataille V, Snieder H, MacGregor AJ, et al. The influence of genetics and environmental factors in the pathogenesis of acne: a twin study of acne in women. J Invest Dermatol 2002; 119: 1317-22.

6. Goulden V, McGeown CH, Cunliffe WJ. The familial risk of adult acne: a comparison between first-degree relatives of affected and unaffected individuals. Br J Dermatol 1999; 141: 297-300.

7. Sobjanek M, Zabłotna M, Nedoszytko B, et al. Lack of association between the promoter polymorphisms at positions -238 and -308 of the tumour necrosis factor alpha gene and acne vulgaris in Polish patients. J Eur Acad Dermatol Venereol 2009; 23: 331-2.

8. Szabó K, Tax G, Kis K, et al. Interleukin-1A +4845(G> T) polymorphism is a factor predisposing to acne vulgaris. Tissue Antigens 2010; 76: 411-5.

9. Al-Shobaili HA, Salem TA, Alzolibani AA, et al. Tumor necrosis factor- $\alpha-308$ G/A and interleukin $10-1082$ A/G gene polymorphisms in patients with acne vulgaris. J Dermatol Sci 2012; 68: 52-5.

10. Tasli L, Turgut S, Kacar N, et al. Insulin-like growth factor-I gene polymorphism in acne vulgaris. J Eur Acad Dermatol Venereol 2013; 27: 254-7.

11. Al Robaee AA, AlZolibani A, Al Shobaili H, Settin A. Association of interleukin $4(-590 \mathrm{~T} / \mathrm{C})$ and interleukin 4 receptor (Q551R A/G) gene polymorphisms with acne vulgaris. Ann Saudi Med 2001; 32: 349-54.

12. Alzoubi KH, Khabour OF, Hassan RE, et al. The effect of genetic polymorphisms of RARA gene on the adverse effects profile of isotretinoin-treated acne patients. Int J Clin Pharmacol Ther 2013; 51: 631-40.

13. Caputo V, Fiorella S, Curiale S, et al. Refractory acne and 21-hydroxylase deficiency in a selected group of female patients. Dermatology 2010; 22: 121-7.

14. He L, Yang Z, Yu H, et al. The relationship between CYP17 -34T/C polymorphism and acne in Chinese subjects revealed by sequencing. Dermatology (Basel) 2006; 212: 338-42.

15. Paraskevaidis A, Drakoulis N, Roots I, et al. Polymorphisms in the human cytochrome P-450 1A1 gene (CYP1A1) as a factor for developing acne. Dermatology (Basel) 1998; 196: 171-5. 
16. Rumianowski B, Adler G, Safranow K, et al. CYP17 and CYP19 genetic variants are not associated with age at natura menopause in Polish women. Reprod Biol 2012; 12: 368-73.

17. Yang Z, Yu H, Cheng B, et al. Relationship between the CAC repeat polymorphism in the androgen receptor gene and acne in the Han ethnic group. Dermatology 2009; 4: 302-6.

18. Sobjanek M, Zabłotna M, Sokołowska-Wojdyło M, et al. Polymorphism in cytochrome P-450 (CYP1A1) in acne vulgaris - preliminary study. Postep Derm Alergol 2007; 24: 69-72.

19. Tian LM, Xie HF, Yang T, et al. Correlation between CYP17 gene polymorphisms and female post adolescent acne in Han population in Hunan Province. Nan Fang Yi Ke Da Xue Xue Bao 2010; 30: 1590-2, 1596.

20. Szabó K, Tax G, Teodorescu-Brinzeu D, et al. TNFalpha gene polymorphisms in the pathogenesis of acne vulgaris. Arch Dermatol Res 2011; 303: 19-27.

21. Baz K, Emin EM, Yazici AC, et al. Association between tumor necrosis factor-alpha gene promoter polymorphism at position -308 and acne in Turkish patients. Arch Dermatol Res 2008; 300: 371-6. 